\title{
Dissemine granüloma anulare ve asemptomatik multipl myelom birlikteliği
}

\section{Coexistence of disseminated granuloma annulare and asymptomatic multiple myeloma}

\author{
Șebnem Aktan, Sevgi Akarsu, Ceylan Canbaz Avcı, Banu Lebe*, Abdullah Katgı**, Güner Hayri Özsan**
}

Dokuz Eylül Üniversitesi Tıp Fakültesi, Deri ve Zührevi Hastalıkları Anabilim Dalı, *Patoloji Anabilim Dalı ve **iç Hastalıkları Hematoloji Anabilim Dalı, İzmir, Türkiye

\section{Özet}

Granüloma anulare (GA) nekrobiyotik dermal papüller ile karakterize, nedeni bilinmeyen, benin, inflamatuvar bir dermatozdur. Literatürde lokalize, dissemine, lineer, nodüler, perforan, subkutanöz, püstüler ve arkuat dermal eritem gibi değişik morfolojik formları bildirilmişsir. Nadir görülen dissemine GA formunun bazı hematopoetik veya solid malignitelerle birlikteliği bildirilse de, malignite ile GA arasındaki kesin nedensel ilişkinin belirsiz olduğu ileri sürülmüştür. Burada asemptomatik multipl myelomun eşlik ettiği dissemine GA'lı 66 yaşında bir kadın olgu sunulmaktadır. (Türkderm 2013; 47: 176-9)

Anahtar Kelimeler: Granüloma anülare, malignite, multipl miyelom

\section{Summary}

Granuloma annulare (GA), which is characterized by necrobiotic dermal papules, is a benign inflammatory dermatosis of unknown cause. Several morphologic forms of GA, including localized, disseminated, linear, nodular, perforating, subcutaneous, pustular, and arcuate dermal erythema have been reported in the literature. Disseminated GA, a rarely seen form, has been reported to be in association with some hematopoietic and solid malignancies, however, it has been suggested that the exact causative relationship between malignancy and GA is unclear. We present here a 66-year-old female patient with disseminated GA associated with asymptomatic multiple myeloma. (Turkderm 2013; 47: 121-418-21)

Key Words: Granuloma annulare, malignancy, multiple myeloma

\section{Giriş}

Nekrobiyotik dermal ve subkutanöz papüller ile karakterize olan granüloma anulare (GA), nedeni bilinmeyen ve genellikle kendini sınılayan benin granülomatöz bir dermatozdur. Tipik lezyonlar zamanla genişleyerek etrafı daha kabarık anuler plaklara dönüşme eğilimi gösteren tek veya çok sayıdaki hafif eritemli papüllerden oluşur. Klinik olarak en sık lokalize formda görülmekle birlikte dissemine, nodüler, perforan, subkutanöz, lineer, püstüler ve arkuat dermal eritem gibi değişik görünümlerde de olabilir1,2. Nadir görülen dissemine formun patogenezi tam olarak bilinmemekle birlikte diyabetes mellitus, tiroid hastalıkları, maligniteler, hepatit B ve $C$ virüsü infeksiyonları, medikasyonlar ve edinsel immün yetmezlik sendromu ile birlikte görülen olgular bildirilmiştir3-7. Burada asemptomatik multipl myelomun eşlik ettiği dissemine GA'lı 66 yaşında bir kadın olgu sunulmaktadır.

\section{Olgu}

Vücudundaki kaşıntılı kızarık kabarıklıklar yakınması ile polikliniğimize başvuran 66 yaşındaki kadın, lezyonlarının yak-

Yazışma Adresi/Address for Correspondence: Dr. Sevgi Akarsu, Dokuz Eylül Üniversitesi Tıp Fakültesi, Deri ve Zührevi Hastalıkları Anabilim Dall, İzmir, Türkiye Tel.: +90 2324123860 E-posta: sevgi.akarsu@deu.edu.tr Geliş Tarihi/Received: 04.05.2011 Kabul Tarihi/Accepted: 23.06.2011 
laşık yedi ay önce karın bölgesinden başlayarak zamanla gövde ve ekstremitelere yayıldığını tanımlamışır. Bu yakınmalarına yönelik anuler elastolitik dev hücreli granülom tanısı aldığı ve önerilen sistemik dapson (1 ay $100 \mathrm{mg} /$ gün, 3 ay 50 mg/gün) tedavisinden belirgin fayda görmediği öğrenilmiştir. Ayrıca hipertansiyon ve aritmi öyküsü olan olgumuz, yaklaşık altı ay önce anemi nedeni ile başvurduğu Hematoloji polikliniğinde sebebi bilinmeyen monoklonal gammopati olarak değerlendirildiğini ve tedavisiz olarak üç aylık aralarla poliklinik kontrollerine geldiğini belirtmiştir. Soygeçmişinde ise annede konjestif kalp yetmezliği ve babada akciğer kanseri olduğu öğrenilen olgumuzun sistem sorgulamasında herhangi bir özellik belirlenmemiştir. Dermatolojik muayenesinde kollar, bacaklar ve gövde üst kısımlarında dağınık yerleşimli, abdominal, inguinal, lomber ve sakral alanlarda ise yer yer birleşme eğilimi gösteren, bazıları anuler tarzda eritemli papüler lezyonlar ve yer yer postinflamatuvar hiperpigmentasyon alanları belirlenmiştir (Resim 1).

Olgumuzun hemogram, rutin biyokimya, tam idrar, tiroid fonksiyon testleri, gaitada gizli kan, anti-HBs, anti-HCV, anti-HIV ve VDRL testi gibi laboratuvar incelemelerinden hemoglobin: 11,2 g/dl (12-16 g/ $\mathrm{dl})$, eritrosit sedimentasyon hızı: $80 \mathrm{~mm} / \mathrm{sa}(0-15 \mathrm{~mm} / \mathrm{sa})$, serum total proteini: 9,4 g/dl (5,8-7,6 g/dl), aspartat aminotransferaz: $54 \mathrm{U} / \mathrm{L}$ (5-34 U/L) ve gama glutamil transferaz: $91 \mathrm{U} / \mathrm{L}$ (9-36 U/L) olarak saptanmıştır. Açlık kan şekeri normal olan olgunun oral glukoz tolerans testine yanıtı 0. dk: $97 \mathrm{mg} / \mathrm{dl}(80-115 \mathrm{mg} / \mathrm{dl})$ ve 2 . saat $125 \mathrm{mg} / \mathrm{dl}$ (<140 mg/dl) olmak üzere normal sınılarda belirlenmiştir. Olgumuzun akciğer grafisi ve abdominopelvik ultrasonografisinde de herhangi bir patoloji saptanmamıştır.

Olgunun sağ bacağındaki eritemli papüler lezyondan alınan "punch" biyopsinin histopatolojik incelemesinde retiküler dermiste lokalize granülomatöz reaksiyon, geniş nekrobiyoz alanı çevresinde genel olarak palizad dizilim gösteren CD68 pozitif ve S100 negatif histiyositik infiltrasyon ile eşlik eden serpilmiş histiyositik dev hücreler ve lenfositler, nekrobiyoz alanında çok belirgin olmamakla birlikte Alcian mavisi ile pozitif boyanan müsin birikimi saptanmıştır (Resim 2).

Eritrosit sedimantasyon hızı yüksekliği nedeniyle yapılan ileri tetkiklerinden serum protein elektroforezinde gama bölgesinde keskin bant görünümü ve serum immünoelektroforezinde IgG-kappa monoklonal gammopati olması nedeni ile Hematoloji bölümünce tekrar değerlendirilen olgudan serum immünglobulin düzeyleri, tüm vücut kemik direkt grafileri ve kemik iliği aspirasyon biyopsisi istenmiştir. Kemik grafilerinde litik lezyon izlenmeyen olgunun yapılan kemik iliği aspirasyon örneğinde \%12 plazma hücresi, kemik iliği biyopsisinde ise \%40 sellülarite gösteren ilik dokusunda interstisyumda kimi alanlarda sayıları hafıfçe artmış ve yer yer küçük kümeler yapmış CD38

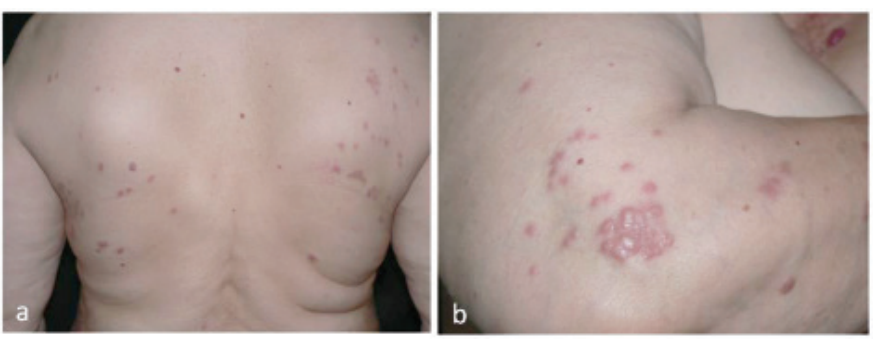

Resim 1. Gövde arka yüzdeki (a) ve sağ kol ekstansör yüzündeki (b) dissemine granüloma anulare kliniği ile uyumlu eritemli papüller pozitif plazma hücreleri saptanmış olup bu hücrelerde ağılıklı olarak kappa pozitifliği gösterilmiştir. Yapılan laboratuvar incelemelerinde lgG: $3633 \mathrm{mg} / \mathrm{dl}$ ve $\mathrm{Hb}:$ 11,8 g/dl olmakla beraber aynı zamanda talasemi taşıyıcısı olduğu belirlenmiştir. Olgumuz kemikte litik lezyon olmaması, ayrıca serum kalsiyum, kreatinin ve tam kan sayımı değerlerinin normal sınırlarda olması nedeniyle asemptomatik multipl myelom olarak değerlendirilmiş ve bu bulgular eşliğinde tedavisiz olarak üç aylık aralarla izlem kararı alınmıştır.

Klinik ve histopatolojik bulgular eşliğinde disemine GA ve asemptomatik multipl myelom birlikteliği olarak değerlendirilen olgumuza sırasıyla uygulanan sistemik PUVA (40 seans) ve dar band UVB (28 seans) tedavileri süresince mevcut lezyonlarda kısmi gerileme olmasına karşın, yeni lezyon çıkışlarının devam ettiği ve/veya tedavi kesildikten sonra yeniden tekrarladığı gözlenmiştir. Daha sonraki izlemlerinde hidroksiklorokin (400 mg/gün) tedavisi başlanan olgu lezyonlarında değişiklik olmaması nedeniyle herhangi bir fayda görmediğini düşünerek ikinci haftadan itibaren tedaviye devam etmek istememiştir.

\section{Tartışma}

Tüm GA'li olguların \%8,5-15'ini oluşturan ve genellikle 30-70 yaş arası kadınları etkileyen dissemine GA'nin lokalize forma göre geç başlangıç yaşı, lezyonların morfolojik görünümü ve yaygın dağılımı,

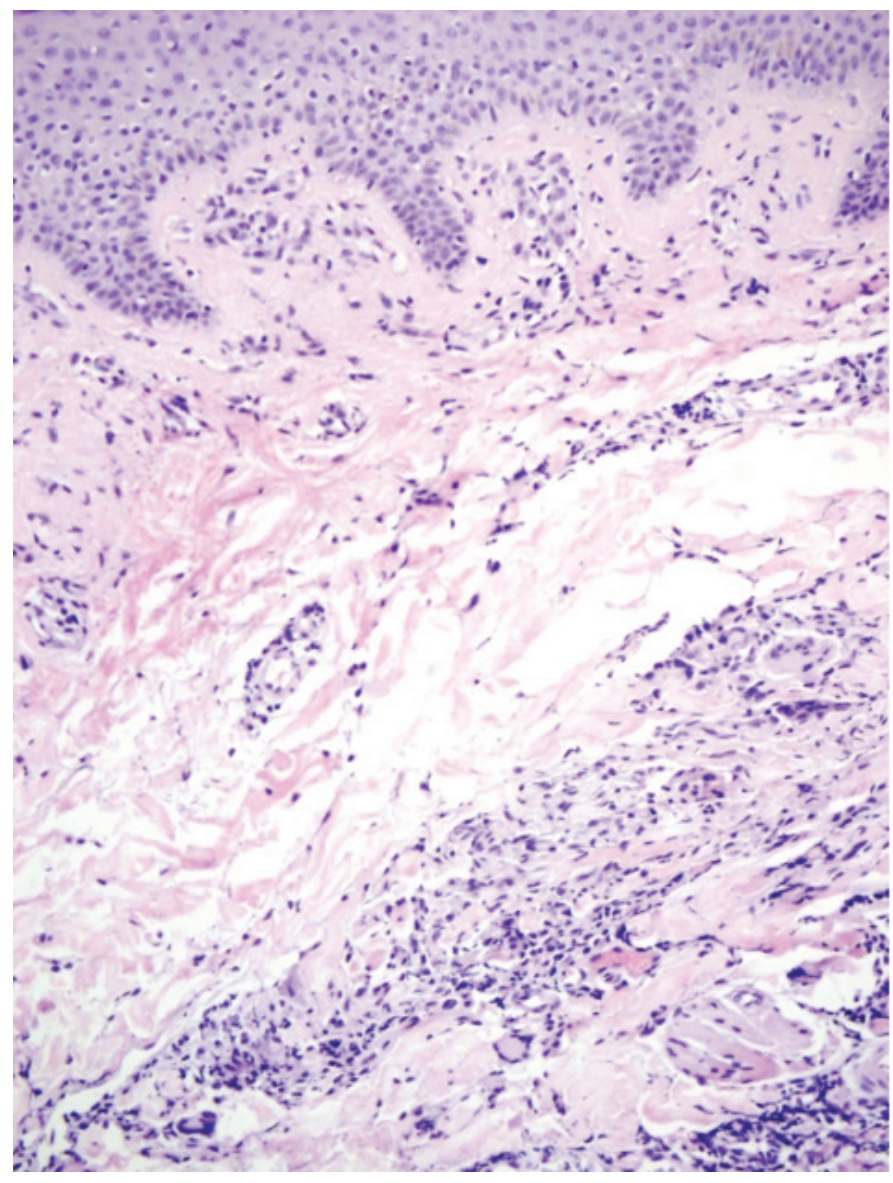

Resim 2. Epidermiste akantoz, dermiste miksoid dejenerasyon gösteren kollajen çevresinde ve interstisiyel paternde histiyositik hücre infiltrasyonu (HEX20) 
diyabetes mellitus ile ilişkisi, uzun süren seyri, spontan gerilemenin çok nadir görülmesi ve tedavilere yanıtının zayıf olması gibi farklı özellikleri bulunmaktadır1,8. Klinik olarak gövde ve ekstremite yerleşimli olan lezyonlar deri renginde, eritemli ya da viyolase renkli, sınırları hafif kabarık dermal papül ya da küçük anuler plaklar ile karakterizedir. Histopatolojik olarak dermiste nekrobiyotik kollajeni çevreleyen histiyositler, lenfositler ve multinükleer dev hücreler saptanmaktadır1,7. Bizim olgumuza da benzer klinik ve histopatolojik bulgular eşliğinde dissemine GA tanısı konulmuştur.

Nadir görülen bu dermatozun oluşumuna neden olan tetikleyici faktör tam olarak bilinmemekle birlikte diyabetes mellitus, tiroid hastalıkları, hipertansiyon, atopi, artrit, irritabl kolon, ülseratif kolit, endometriyozis, hepatit B ve C virusu enfeksiyonu, yaygın sarkoptes skabiei infestasyonu, edinsel immün yetmezlik sendromu, sifiliz, çeşitli medikasyonlar ve malignitelerle ilişkili olarak görülebileceği bildirilmiştir3,7,9

Literatürde bildirilmiş olan GA ile ilişkili maligniteler arasında çeşitli solid organ maligniteleri, schwannoma, granülomatöz mikozis fungoides, lenfoma, akut myelositik lösemi, kronik myelomonositik lösemi ve miyelodisplatik sendrom bulunmaktadır. Bu malignitelerden ise başta Hodgkin lenfoma olmak üzere lenfomalarla birlikteliğinin daha sık olduğu bildirilmiştir4,5,10-13. Dabski ve Winkelmann tarafından yapılan bir çalışmada disemine GA'li olguların \%14'ünde lezyonların oluşumundan önce veya sonra bir iç organ malignitesi saptanmış, ancak her iki tablonun ortaya çıkış süreleri arasındaki geniş varyasyon nedeni ile aralarındaki olası nedensel ilişkinin tartışmalı olduğu ileri sürülmüştür2. GA ile malignite arasındaki ilişkinin mekanizması tam olarak bilinmemekle birlikte tanımlanmamış bir tümör antijeni tarafından tetiklenen immünolojik bir reaksiyon sonucu ortaya çıktığı düşünülmektedir. Tümör hücrelerinin granülom oluşumuna yol açan fibroblastların aktivasyonunu sağlayan sitokinlerin salınımını doğrudan veya dolaylı olarak arttırabileceği ileri sürülmüştür. Ayrıca bu olguların malignitelere karşı hücresel immünitesinin azalmış olabileceğinden de bahsedilmiştir 12 .

Literatürdeki olguların çoğunda malignite tanısı GA lezyonları çıkmadan önce konulmuş olup, nadiren önceden var olan tanı almamış malignite ya da metastaz ile eş zamanlı olarak GA lezyonlarının oluşabildiği ve malignitenin tedavisinden sonra lezyonlarda da gerileme izlenebildiği bildirilmiştir4. Genellikle her iki tablo arasındaki zaman aralığı malignitenin erken evrelerde asemptomatik olması ve gözden kaçması nedeni ile kesin olarak değerlendirilemese de, malignite tanısının GA lezyonlarından 18 ay öncesi ile yedi yıl sonrasına kadar değişen bir süre içinde konulabileceğinden bahsedilmiştir5,10. Lösemi veya lenfoması olan çocuk olgularda da GA geliştiği bildirilmiş olmasına rağmen, GA'li olgularda malignite birlikteliğindeki bu artışın yaşlı populasyondaki artmış malignite sıklığına bağlı olabileceği de ileri sürülmüştür. Bununla birlikte özellikle ileri yaştaki ve atipik klinik görünümü olan GA'li olgularda altta yatan malignite intimalinin göz önünde bulundurulması gerektiği vurgulanmıştır10.

Olgumuzun klinik ayırıcı tanısında ilk olarak düşünülmüş olan anuler elastolitik dev hücreli granülom genellikle yüz, boyun ve el sırtı gibi aktinik hasarlı deride görülmekle birlikte nadiren güneş görmeyen yerlerde de lokalize olabilen GA benzeri eritemli anuler lezyonlarla karakterizedir. Bununla birlikte histopatolojik olarak GA'de izlenen palizat yapan granülomlar, nekrobiyoz ve müsin birikimi görülmemektedir ${ }^{14}$.

Hematolojik malignitelerle birlikte görülebilen granülomatöz infiltrasyonların ayırıı tanısında ayrıca lösemi kutise eşlik eden granülomatöz infiltrasyon, interstisyel granülomatöz dermatit, palizad yapan nötrofilik granülomatöz dermatit ve granülomatöz ilaç reaksiyonları yer almaktadır. Miyeloid displazi ve lösemilerle ilişkili olarak tanımlanan granülomatöz infiltrasyonlarda santral nekroz gösterebilen düzgün şekilli granülomlar bulunmaktadır ${ }^{13}$. Interstisyel granülomatöz dermatitte gövde ve aksiller bölgelerdeki lineer dizilimli lezyonların histopatolojisinde seyrek nötrofilik kırıntılar, eozinofiller, nekrobiyotik kollajen ve palizad yapmış histiyositik infiltrasyon görülür. Palizad yapan nötrofilik granülomatöz dermatitte ise genellikle dirseklerde izlenen ve göbeklenme gösteren kurutlu papüllerin histopatolojisinde bazen vaskülit ile birlikte yoğun nötrofilik ve interstisyel histiyositik infiltrasyon saptanır7. Geniş bir klinikopatolojik spektruma sahip olan ilaç reaksiyonlarında da reaktif proçesin bir parçası olabilen granülomlar iyi şekillenmiş epiteloid topluluklar veya interstisyel dermatit şeklinde görülebilir13. Bizim olgumuzda ilaç kullanımı öyküsünün olmaması, ayrıca histopatolojik olarak nötrofilik ve eozinofilik komponentin yokluğu bu granülomatöz infiltrasyonların ayırıcı tanısında yardımcı olmuştur.

Literatürde özellikle lgG-kappa monoklonal gammopati ile ilişkili olarak görülen ve histapatolojik olarak GA'nin ayırıcı tanısına giren bir diğer histiyositikgranülomatöz derihastalığınekrobiyotikksantogranülomadır. Bu olgularda multipl myelomun ya eşlik ettiği ya da daha sonra ortaya çıkığı görülmüştür7. Bununla birlikte literatürde GA ve multipl myelom birlikteliği günümüze kadar bildirilmemiştir. Nekrobiyotik ksantogranüloma klinik olarak genellikle periorbital alanı etkilemekle birlikte daha az oranda gövde ve ekstremiteleri tutan, bazen yüzeyinde telenjiektazi ve ülserasyon izlenebilen ksantomatöz görünümlü eritemli papül, nodül veya plaklar ile karakterizedir. Histopatolojik olarak ise GA'den farklı olarak lipid depolanması gösteren köpüksü makrofajlar ve histiyositler ile elastik lif kaybı görülmektedir?. Bizim olgumuzda da IgG-kappa monoklonal gammopati belirlenmiş olmakla birlikte klinik ve histopatolojik bulguların eşliğinde nekrobiyotik ksantogranüloma tanısı dışlanmıştır.

Multipl myelom plazma hücrelerinin monoklonal malign proliferasyonu ile karakterize olup tüm malignitelerin \%1'ini, hematolojik malignitelerin ise yaklaşık \%10'nu oluşturur. En sık kemik ağrısı olmak üzere tekrarlayan bakteriyel infeksiyonlar ve böbrek yetmezliği gibi değişik klinik bulgularla ortaya çıkabilir15. Asemptomatik multipl myelom ise uç organ tutulumu olmaksızın serum $M$ proteininin 3 $\mathrm{gr} / \mathrm{dl}$ üzerinde ve/veya kemik iliği plazma hücre oranının \%10'un üzerinde olmasıyla karakterize premalign proliferatif bir plazma hücresi hastalığıdır. Bu gruptaki olguların klinik seyri önemli ölçüde değişken olup semptomatik hastalığa ilerlemesi ortalama 1-2 yıl olarak ifade edilmektedir 16,17

Sonuç olarak olgumuz konvansiyonel tedavilere yanıt alınamayan, ileri yaştaki atipik GA veya GA benzeri granülomatöz dermatiti olan olguların olası solid veya hematolojik maligniteler açısından dikkatli değerlendirilmesi gerekliliğini vurgulamak amacıyla sunulmuştur.

\section{Kaynaklar}

1. Yun JH, Lee JY, Kim MK, et al: Clinical and pathological features of generalized granuloma annulare with their correlation: a retrospective multicenter study in Korea. Ann Dermatol 2009;21:113-9.

2. Dabski K, Winkelmann RK: Generalized granuloma annulare: clinical and laboratory findings in 100 patients. J Am Acad Dermatol 1989;20:39-47. 
3. Studer EM, Calza AM, Saurat JH: Precipitating factors and associated diseases in 84 patients with granuloma annulare: a retrospective study. Dermatology 1996;193:364-8.

4. Cohen PR: Granuloma annulare associated with malignancy. South Med J 1997;90:1056-9.

5. Shimizu S, Yasui C, Tsuchiya K: Atypical generalized granuloma annulare associated with two visceral cancers. J Am Acad Dermatol 2006;54(Suppl 5):236-8.

6. Çalıkoğlu E, Anadolu R, Bovyat A, Peksarı Y: A case of generalized granuloma annulare. Turkiye Klinikleri J Dermatol 1999;9:33-6.

7. Hawryluk EB, Izikson L, English JC 3rd: Non-infectious granulomatous diseases of the skin and their associated systemic diseases: an evidence-based update to important clinical questions. Am J Clin Dermatol 2010;11:171-81.

8. Dabski K, Winkelmann RK: Generalized granuloma annulare: histopathology and immünopathology. Systematic review of 100 cases and comparison with localized granuloma annulare. J Am Acad Dermatol 1989;20:28-39.

9. Piana S, Pizzigoni S, Tagliavini E, Serra S, Albertini G: Generalized granuloma annulare associated with scabies. Am J Dermatopathol 2010;32:518-20.

10. Li A, Hogan DJ, Sanusi ID, Smoller BR: Granuloma annulare and malignant neoplasms. Am J Dermatopathol 2003;25:113-6.
11. Polat M, Gür G, Öztaş $P$, et al: Disseminated granuloma annulare associated with acute myelogenous leukemia: case report. Turkiye Klinikleri J Med Sci 2008;28:980-3

12. Aşkin U, Durdu M, Senel E: Generalized granuloma annulare in a patient with myelocytic leukemia and chronic hepatitis B virus infection. Indian J Dermatol Venereol Leprol 2009;75:287-9.

13. Hinckley MR, Walsh SN, Molnár I, et al: Generalized granuloma annulare as an initial manifestation of chronic myelomonocytic leukemia: a report of 2 cases. Am J Dermatopathol 2008;30:274-7.

14. Limas C: The spectrum of primary cutaneous elastolytic granulomas and their distinction from granuloma annulare: a clinicopathological analysis. Histopathology 2004;44:277-82.

15. Bolaman AZ: Diagnosis of multiple myeloma and criteria for response. Turkiye Klinikleri J Hem Onc-Special Topics 2008;1:1-4.

16. Madan S, Kyle RA, Greipp PR Plasma cell labeling index in the evaluation of smoldering (asymptomatic) multiple myeloma. Mayo Clin Proc 2010;85:300.

17. Kyle RA, Remstein ED, Therneau TM, et al: Clinical course and prognosis of smoldering (asymptomatic) multiple myeloma. $N$ Engl J Med 2007;356:2582-90. 